\title{
EPISTEMOLOGI DAN KETERBATASAN TEORI GRAVITASI
}

\author{
Erwin $^{1^{\star}}$, Muhammad Syaipul Hayat ${ }^{2}$ dan, Sutarno ${ }^{2}$ \\ ${ }^{1}$ Program Studi Pendidikan Fisika STKIP Nurul Huda, Sukaraja, OKU Timur, Sumatera Selatan \\ 2Program Studi Pendidikan Biologi FPMIPATI Universitas PGRI Semarang \\ ${ }^{3}$ Program Studi Pendidikan Fisika FKIP Universitas Bengkulu \\ *Email: erwinpohan74@stkipnurulhuda.ac.id
}

\begin{abstract}
Abstrak
Peristiwa tentang kecenderungan jatuhnya benda-benda menuju pusat bumi dan keteraturan peredaran planet dan benda-benda langit lainnya dalam tata surya dahulu dianggap dua fenomena yang berbeda. Mekanika benda langit dan mekanika bumi yang sebelumnya merupakan dua pengetahuan yang terpisah, dianggap satu kesatuan oleh Sir Isaac Newton. Newton mengemukakan hukum gravitasi umum yaitu gaya tarik menarik antara dua benda besarnya sebanding dengan massa masing-masing benda dan berbanding terbalik dengan kuadrat jarak antara kedua benda. Hukum gravitasi ini sukses menjalaskan bagaimana benda cendrung jatuh menuju pusat bumi dan peredaran planet dan benda-benda langit lain mengelilingi matahari dalam sistem tata surya. Namun hukum gravitasi Newton ternyata tidak sepenuhnya tepat, beberapa hal dapat dijelaskan dengan hukum relativitas Einstein, namun demikian hukum relativitas Einstein juga dicurigai masih perlu diamandemen agar dapat menjelaskan fenomena alam dengan tepat.
\end{abstract}

Kata kunci: Epistemologi, Gravitasi.

\section{PENDAHULUAN}

Kemajuan zaman yang semakin pesat dan semakin modern membuat manusia juga semakin haus terhadap ilmu pengetahuan. Banyak observasi yang dilakukan dan instrumen yang diciptakan sebagai sarana untuk memenuhi keingintahuan manusia terhadap fenomena alam semesta, pengetahuan yang diperoleh kemudian dimanfaatkan untuk kehidupan manusia itu sendiri. Berbagai macam alat dibuat dengan menggunakan teknologi untuk mempermudah pekerjaan. Namun tidak begitu saja dapat menjawab pertanyaan-pertanyaan manusia mengenai alam semesta.

Ketika manusia masih mengalami keterbatasan peralatan dan pengetahuan, mereka hanya menggunakan panca indra dan kemampuan akal berpikir mengenal sifat-sifat alam dan berusaha mnjawab pertanyaan yang mendasar tentang gejala-gejala alam yang dijumpai. Karena hasil pemikiran tersebut tanpa didukung oleh bukti-bukti empiris yang dapat dipertanggungjawabkan mengakibatkan hasil pemikiran tersebut hanya sebatas pernyataan hipotetik saja dan cendrung besifat filosofis, maka tidak mengherankan ketika di kemudian hari banyak dari pemikiran mereka tergantikan oleh teori-teori baru yang didasarkan pada fakta-fakta empiris.

Sejak dahulu hingga sekarang selalu saja muncul pertanyaan yang menggelitik, namun sebenarnya pertanyaan tersebut pada hakekatnya bersifat fundamental, salah satu diantaranya adalah apa penyebab peristiwa tentang kecendrungan jatuhnya benda-benda menuju pusat bumi dan keteraturan peredaran planet dan benda-benda langit lainnya dalam tata surya?. Pada zaman dahulu kedua fenomena tersebut dianggap fenomena yang berbeda. Hal ini disebabkan karena kedua fenomena itu saling lepas dan tidak ada hubungan satu sama lain. Peristiwa kecendrungan jatuhnya benda-benda menuju pusat bumi sepintas tidaklah peristiwa aneh, karena kejadian tersebut lumrah terjadi dalam kehidupan sehari-hari. Tetapi apakah terpikirkan mengapa benda-benda tersebut jatuh menuju pusat bumi bukan sebaliknya menjauhi bumi?

Pertanyaan di atas dan yang sejenisnya bukan pertanyaan sederhana karena telah banyak ilmuwan pada abad ke 16 dan 17 yang berusaha mendapatkan jawaban terhadap pertanyaan tersebut.

Pada awalnya orang menganggap bahwa benda jatuh adalah kejadian biasa yang sudah terjadi umum, sehingga tidak perlu diperdebatkan. Namun saat ini pemahaman tentang kejadian ini dijelaskan 
dengan konsep gravitasi. Pertanyaannya adalah bagaimanakah epistemologi gaya gravitasi?. Artikel ini mencoba memaparkan jawaban atas pertanyaan tersebut.

\section{HASIL DAN PEMBAHASAN}

\section{Epistemologi}

Perkembangan ilmu pengetahuan tidak lepas dari peran filsafat sebagai cara berpikir yang radikal dan menyeluruh, cara berpikir yang mengupas segala sesuatu sedalam-dalamnya (Suriasumantri, 2009). Terdapat empat hal yang melahirkan filsafat, yaitu ketakjuban (keheranan) terhadap sesuatu yang dilihat atau dirasakan, ketidakpuasan jawaban yang diperoleh karena didasarkan pada mitos tentang gejala alam, sifat keingintahuan manusia tentang segala sesuatu, dan keraguan terhadap jawaban yang sudah ada serta ingin mendapatkan jawaban yang lebih benar (Rapar, 1995).

Berdasarkan hal-hal yang melahirkan filsafat sebagaimana diungkapkan Rapar tersebut, maka kajian filsafat memiliki tiga unsur pokok yaitu epistemologi (teori pengetahuan), ontologi (teori keberadaan objek ilmu), dan aksiologi (teori penggunaan ilmu) (Firman, 2017).

Salah satu bagian yang paling penting dari ilmu pengetahuan adalah kajian epistemologi, asal kata epistemologi adalah episteme yang berasal dari bahasa Yunani yang berarti pengetahuan, dan logos yang berarti ilmu, maka epistemologi didefinisan sebagai cabang filsafat yang mempelajari asal mula atau sumber, struktur, metode dan sahnya (validnya) pengetahuan. (http://www.eurekapendidikan.com/2014/10/hakikat-epistimologi-dalam-kajian-Filsafat_llmu.html)

Epistemologi merupakan pembahasan mengenai bagaimana mendapatkan pengetahuan atau lebih menitikberatkan pada sebuah proses pencarian ilmu : apakah sumber-sumber pengetahuan?, apakah hakekat, jangkauan dan ruang lingkup pengetahuan?, sampai tahap mana pengetahuan yang mungkin untuk ditangkap manusia?. (Suriasumantri, 2005).

Epistemologi dalam filsafat terus mendorong manusia untuk selalu berpikir bagaimana menemukan dan menciptakan sesuatu yang baru atau mencari jawaban terhadap sesuatu yang masih menjadi pertanyaan atau jawaban yang masih diragukan kebenarannya, sehingga filsafat selalu ingin mencari kebenaran yang hakiki tentang pengetahuan. Semua teknologi dan karya manusia merupakan hasil pemikiran manusia secara epistemologi, yaitu perenungan dan pemikiran tentang bagaimana menciptakan sesuatu yang dapat membantu manusia dan meningkatkan kesejahteraan manusia.

\section{Teori Gravitasi Klasik}

Perbincangan tentang gerak benda-benda sudah dilakukan jauh sebelum Newton menjelaskan tentang alasan mengapa benda bergerak. Gerak benda merupakan cabang fisika yang sangat berkaitan erat dengan bidang fisika lainnya, sehingga mempelajari gerak merupakan hal yang sangat penting dan ilmiah. Banyak ilmuwan yang tertarik dan sibuk mempelajari tentang gerak termasuk diantaranya Aristoteles, seorang filsuf dan ilmuwan yang banyak menuangkan hasil pemikirannya tentang gerak.

Aristoteles (384 SM - $322 \mathrm{SM}$ ) membagi gerak menjadi dua kelompok besar yaitu : gerak alami (pure motion) dan gerak paksa (violent motion) (Stiyani, 2014).

Menurut Aristoteles gerak alami berkaitan dengan sifat bawaan dari berbagai benda yang merupakan sifat intrinsik khusus dari benda itu sendiri. Aristoteles menyifati berbagai benda menurut kedekatan sifat-sifatnya terhdap elemen dasar benda itu. Misalnya jika benda bergerak sentripetal dan gerak jatuh bebas merupakan gerak alamiah dari sifat air dan tanah (bumi). Sedangkan benda yag bergerak sentrifugal dan loncatan ke atas merupakan sifat alamiah api dan udara dan gerak sirkuler (melingkar) adalah gerak alamiah dari sifat eter.

Gerak paksa menurut Aristoteles adalah gerak benda yang disebabkan adanya pengaruh luar terhadap benda dan arahnya dapat ke sembarang arah seperti dorongan dan tarikan yang berasal bukan dari benda itu sendiri. Lebih lanjut Aristoteles juga menyatakan bahwa benda hanya akan bergerak apabila benda tersebut diberi gaya, gerak benda akan berhenti apabila gaya dihilangkan, 
artinya gerak paksa itu akan terjadi apabila benda tersebut diberikan gaya terus menerus.

Pemahaman Aristoteles mengenai percepatan benda didasarkan pada berat benda, maksudnya benda yang memiliki berat yang lebih besar akan lebih cepat jatuh ke tanah dibandingkan dengan benda yang lebih ringan. Dengan demikian kecepatan jatuhnya benda merupakan proporsi dari berat bendanya. Contoh yang diberikan untuk mendukung pemahaman Aristoteles ini adalah : apabila ada benda yang beratnya sama dengan berat udara maka benda tersebut akan melayang tidak jauh dan tidak naik, apabila benda beratnya lebih besar dari berat udara maka benda akan jatuh, selanjutnya benda yang beratnya lebih kecil daripada berat udara akan bergerak naik. Menurut pemahaman tersebut maka berat benda mempengaruhi gerak jatuh benda.

Berkaitan dengan pergerakan benda-benda langit, Aristoteles menyatakan bahwa pergerakan benda-benda langit itu sangat sempurna terus menerus karena adanya kekuatan yang diberikan oleh sang pencipta. Aristoteles belum mengenal adanya gaya gravitasi, dan ia percaya bahwa bumi merupakan pusat tata surya.

Plato (427-347 SM) salah satu ilmuwan Yunani mengemukakan pendapat yang berkaitan dengan gravitasi, bahwa bintang dan bulan bergerak mengelilingi bumi membentuk suatu lintasan berbentuk lingkaran sempurna. Selanjutnya Claudius Ptolemaus pada abad ke-2 Masehi memberikan dukungan pada pendapat Plato yang kemudian dikenal dengan teori geosentris. Menurut teori geosentris bumi merupakan pusat tata surya, oleh karena itu planet lain seperti bulan dan matahari berkeliling mengitari bumi. Namun pendapat ini tidak dapat menjelaskan gerakan yang rumit dari planet-planet.

Teori geosentris yang dikemukakan oleh Plato dan Ptolemaus dibantah oleh Nicolas Copernicus (1473-1543) seorang ilmuwan yang berkebangsaan Polandia. Copernicus berusaha mencari jawaban atas kelemahan teori geosentris dengan mengemukakan teori bahwa matahari sebagai pusat tata surya, sehingga bumi dan planet-planet lainlah yang berputar mengelilingi matahari. Akibat pendapat yang dikemukakan oleh Copernicus ini terjadi pertentangan diantara para ilmuwan pada saat itu, sehingga para ilmuwan berlomba mencari bukti melalui pencarian data yang teliti untuk membuktikan kebenaran teori yang sedang dipertentangkan tersebut.

Tyco Brahe (1546-1601) berhasil menyusun data mengenai gerak planet secara teliti. Data yang disusun Tyco kemudian dipelajari oleh Johannes Keppler (1571-1630). Keppler menemukan keteraturan gerak planet berdasarkan data yang disusun oleh Tyco, berdasarkan keteraturan tersebut Keppler mengemukakan tiga aturan mengenai gerak planet, aturan yang dikemukakannya dikenal dengan Hukum I, II dan III Keppler. Hukum-hukum Kepler berbunyi sebagai berikut:

1. Lintasan setiap planet ketika mengelilingi matahari berbentuk elips, dimana matahari terletak pada salah satu fokusnya.

2. Luas daerah yang disapu oleh garis antara matahari dengan planet adalah sama untuk setiap periode waktu yang sama.

3. Kuadrat waktu yang diperlukan oleh planet untuk menyelesaikan satu kali orbit sebanding dengan pangkat tiga jarak rata-rata planet-planet tersebut dari matahari (http://www.fisikainfo.com/2015/11/sejarah-perkembangan-teori-gravitasi.html\#).

Pendapat Copernicus dan hukum Keppler memiliki kesamaan bahwa gaya sebagai penyebab keteraturan gerak planet dalam tata surya.

\section{Teori Gravitasi Modern}

Pemikiran tentang fenomena benda jatuh yang dikemukakan Aristetoles bahwa benda yang memiliki berat yang lebih besar akan jatuh lebih cepat mencapai tanah dibandingkan dengan benda yang memiliki berat yang lebih ringan, dan bahwa laju jatuhnya benda sebanding dengan berat benda bertahan sampai munculnya gagasan baru Galileo (1564-1642). Galileo menyatakan bahwa semua benda apabila jatuh akan mengalami percepatan yang sama jika benda tersebut tidak mengalami hambatan dan berada dalam ruang hampa. Sebuah benda yang jatuh dari keadaan diam akan memiliki jarak tempuh yang sebanding dengan kuadrat waktu. Argumen cerdik yang berikan Galileo adalah apabila sebuah benda yang berat dijatuhkan dari keinggian 2 meter akan memukul sebuah tiang pancang lebih dalam dibandingkan dengan batu yang sama dijatuhkan dari ketinggian 20 centimeter. 
Menurut Galileo jelas batu tersebut bergerak lebih cepat pada ketinggian yang pertama.

Selanjutnya Galileo juga menunjukkan bahwa selembar kertas dan sebuah bola yang dijatuhkan dari ketinggian yang sama pada saat yang bersamaan, maka bola akan mencapai tanah terlebih dahulu. Tetapi apabila percobaan tersebut diulang dengan membentuk kertas tersebut menjadi gumpalan kecil akan terlihat bahwa kedua benda akan mencapai tanah pada saat yang hampir bersamaan. Pada percobaan ini Galileo yakin bahwa udara menghambat benda-benda yang ringan dan memiliki permukaan yang luas. Makanya, saat logam dan bulu dijatuhkan bersamaan di suatu kolom vakum, keduanya mencapai dasar dalam waktu yang bersamaan.

Percobaan menggunakan bandul yang dilakukan oleh Galileo menunjukkan bahwa semakin pendek tali bandul maka waktu yang diperlukan untuk satu kali ayunan semakin pendek, dengan kata lain gerakan bandul semakin cepat. Selain itu menurut Galileo kita tidak dapat jatuh dari bumi karena bumi memiliki gaya berat. Semua benda mempunyai berat namun titik pusat berat benda tidak selalu di tengah-tengah benda. Benda dapat diibaratkan sebagai matahari yang begitu besar sehingga mampu menarik planet-planet yang ada di sekitarnya, tetapi planet-planet juga berusaha mempertahankan kedudukannya sehingga planet akan bergerak lebih cepat pada saat berada pada posisi yang terjauh dari matahari dan akan bergerak lebih lambat saat berada pada posisi paling dekat dengan matahari. Karena gerakan planet yang demikian menyebabkan bentuk orbitnya ellips. Prinsip bandul yang dikemukakan oleh Galileo ini dikenal dengan istilah isochronism yang berarti keseragaman waktu. Prinsip ini juga dapat digunkan untuk mengukur pergerakan bintang-bintang dan mengontrol waktu yang merupakan awal dari dinamika pengetahuan modern yang berhubungan dengan hukum-hukum gerakan dan gaya.

Berkaitan dengan pergerakan benda-benda langit, Galileo merupakan salah satu ilmuan yang mengikuti pendapat Copernicus, namun yang menjadi masih misteri baginya adalah pertanyaan "jika bumi memang bergerak mengelilingi matahari, mengapa kita tidak merasakannya?, kemudian karena bumi bergerak, apabila ada sebuah benda yang jatuh dari ketinggian tertentu maka benda tersebut tidak akan jatuh tepat dibawah titik jatuhnya melainkan agak bergeser dari titik semula, dan menurut perhitungan Galileo seharusnya benda tersebut jatuh 0,5 mil dari titik tersebut. Penjelasan Galileo tentang hal ini adalah bahwa saat benda jatuh, bumi dan benda tersebut bergerak horizontal tanpa kita rasakan. Benda bergerak pada kecepatan horizontal yang sama dengan bumi sambil tetap bergerak vertikal ke bawah sehingga jatuh tepat di bawah titik awal jatuhnya benda.

Benda yang jatuh dari suatu ketinggian selalu jatuh ke bawah merupakan hal yang sudah dianggap lumrah dan biasa, namun apakah pernah dipikirkan mengapa benda itu jatuh selalu menuju pusat bumi dan tidak pernah sebaliknya naik ke atas atau diam saja ditempatnya?

Menjelang berakhirnya abad ke-17 Sir Isaac Newton (1642-1727), seorang ilmuwan inggris, berhasil menyingkap teka-teki alam yang menarik perhatian itu. Sebagian orang menceritakan bahwa jawaban tentang teka-teki itu diperoleh Newton ketika sebuah apel jatuh ke kepalanya sewaktu ia sedang merenungi masalah ini di bawah sebuah pohon apel di pekarangan rumahnya. (apakah kejadian jatuhnya buah apel yang menimpa kepala Newton ini benar? Masih diragukan kebenarannya) (Wospakrik, 1987). Namun menurut cerita, kejadian ini yang mengilhami Newton menemukan hukum yang kemudian dikenal dengan "hukum gravitasi newton".

Hukum gravitasi yang dikemukakan Newton menyatakan bahwa dua buah benda yang terpisah oleh jarak tertentu cendrung akan saling tarik menarik yang merupakan gaya alamiah, besarnya gaya alamiah ini sebanding dengan massa masing-masing benda dan berbanding terbalik dengan kuadrat jarak antara kedua benda. Secara matematika peryataan hukum gravitasi Newton itu dapat dituliskan: , dengan $\mathrm{G}$ adalah tetapan gravitasi $=6,67 \cdot 10^{-11} \mathrm{Nm}^{2} / \mathrm{kg}^{2}, \mathrm{~m}_{1}$ dan $\mathrm{m}_{2}$ masing-masing adalah massa benda pertama dan massa kedua, serta $r$ adalah jarak pisah antara kedua benda. Mekanika benda langit dan mekanika bumi yang sebelumnya merupakan dua pengetahuan yang terpisah, dianggap satu kesatuan oleh Sir Isaac Newton.

Bila dilihat kembali pertanyaan di atas, dimana terdapat dua buah benda yang saling mempengaruhi, yaitu bumi dan benda yang jatuh menuju pusat bumi. Menurut Newton antara bumi dan 
benda timbul gaya tarik menarik, dimana bumi menarik benda sedangkan benda juga menarik bumi. Gaya tarik bumi terhadap benda disebut gaya berat atau gaya gravitasi dan lebih sering dikenal dengan berat benda. Sebaliknya juga berlaku tarikan yang sama dilakukan benda kepada bumi yang besarnya sama. Dalam hukum yang dinyatakan Newton tersebut, jarak antara benda dengan bumi dihitung dari benda ke pusat bumi yang berada sekitar 4.670 kilometer di bawah permukaan bumi.

Dengan bantuan hukum gravitasi Newton ini orang mulai memahami penyebab kecendrungan jatuhnya benda menuju pusat bumi, namun demikian masih ada pertanyaan lanjutan yang mengganjal dalam pikiran orang yaitu mengapa benda yang jatuh menuju pusat bumi, bukan sebaliknya bumi yang tertarik menuju benda?

Berkaitan dengan pergerakan planet dalam tata surya ternyata saat itu hukum gravitasi Newton berhasil menjelaskan bagaimana mekanisme dua buah objek bermassa yang berinteraksi dalam gaya tarik menarik gravitasi. Matahari dalam sisten tata surya menurut teori ini memiliki gaya tarik yang sangat besar jangkauannya sehingga menarik benda-benda angkasa yang bermasaa relatif kecil planet, komet, asteroid melayang pada orbitnya.

\section{Keterbatasan Hukum Gravitasi Newton}

Keberhasilan Newton menemukan hukum gravitasi dapat menjelaskan bagaimana kerja gravitasi pada situasi atau kondisi normal, kemudian hukum gravitasi tersebut dikenal dengan hukum gravitasi universal newton. Pada jaman dahulu hukum gravitasi newton dipadukan dengan hukum kepler untuk mencari letak benda-benda langit dan menghitung massanya. Kesederhanaan perhitungan yang dilakukan Newton membuat orang awam mudah menerima hukum gravitasinya. Tapi kenyataannya alam semesta tidaklah sesederhana itu, karena alam semesta terdiri dari milyaran bahkan trilyunan benda-benda ruang angkasa yang saling mempengaruhi letak yang satu dengan lainnya. Ternyata bumi dan tata surya hanyalah sebagian kecil dari isi yang ada di jagat raya ini.

Pada awal abad ke-20 Einstein mengajukan teori relativitas khusus yaitu tahun 1905, kemudian Einstein menemukan kejanggalan dan ketidakcocokan teori gravitasi newton dengan teori relativitas yang diajukannya.

Einstein berusaha agar teori relativitas khusus yang diajukannya konsisten dengan teori elektromagnetik yang dikemukakan oleh Maxwell. Maxwell sendiri adalah pengikut Newton yang percaya bahwa cahaya dan elektromagnetisme pada umumnya disebabkan oleh perpindahan partikelpartikel eter mekanis yang bervariasi (Kuhn, 2008). Dalam usaha mengkonsistenkan teori tersebut Einstein tiba pada suatu klaim yang menyatakan bahwa cahaya memiliki kecepatan 299.792 km/detik dan kecepatan ini menurutnya adalah kecepatan absolut, artinya kecepatan ini adalah kecepatan terbesar di jagad raya, benda atau energi lain tidak akan pernah melebihi kecepatan cahaya ini. Prinsip fisik lain yang tidak bersesuaian dengan teori gravitasi newton menurut Einstein adalah prinsip ekuivalen. Newton sendiri tidak menjelaskan bagaimana gaya gravitasi itu bekerja, ia hanya mengatakan bahwa gravitasi adalah gaya yang sudah dari sananya dimiliki oleh benda yang bermassa. Newton hanya mengatakan bahwa sebuah benda yang bermassa akan mengerjakan gaya tarik kepada benda bermassa lainnya yang berada dalam jangkauan gaya gravitasi benda yang bermassa lebih besar. Gaya tarik gravitasi antara dua benda tersebut menjelajah ruang hampa di antara dua benda tadi dalam waktu sesaat.

Ambillah gambaran sederhana bahwa sistem gravitasi antara bumi - matahari menurut Newton dinamikanya dikontrol oleh persamaan :, dengan $r$ adalah jarak rata-rata bumi - matahari yaitu 150 juta $\mathrm{km}$. Apabila dianggap tiba-tiba matahari meledak dan lenyap seketika, maka gaya tarik menarik antara bumi-matahari seketika juga akan hilang, dengan selang waktu yang tidak bisa diukur karena cepatnya. $\mathrm{Hal}$ ini bertentangan dengan teori relativitas khusus Einstein karena tidak ada benda atau energi yang melampaui kecepatan cahaya. Bila dihitung berdasarkan data bahwa jarak bumi matahari 150 juta km, kecepatan cahaya $299.792 \mathrm{~km} /$ detik, akan diperoleh bahwa dibutuhkan waktu 8,33 menit agar bumi merasakan kehilangan gaya tarik menarik tersebut jika dianggap kecepatan energi gaya sama dengan kecepatan cahaya. Sehingga hukum gravitasi newton semakin menunjukkan perlunya ada koreksi.

Jangkauan gaya gravitasi mencapai ribuan bahkan jutaan kilometer, maka gaya gravitasi tidak 
mungkin menjelajah ruang angkasa dalam waktu yang sangat singkat. Jika gaya gravitasi bergerak sama dengan cara bergeraknya cahaya, maka menurut Einstein kecepatan gaya gravitasi tidak boleh melebihi kecepatan cahaya. Oleh karena itu, dengan jarak jangkauan yang jauh maka jelas gaya gravitasi memerlukan waktu yang panjang untuk menjelajah ribuan atau bahkan jutaan kilometer, tidak mungkin bisa dijelajah dalam waktu sekejap.

Meskipun teori gravitasi Newton ada pertentangan dengan teori relativitas khusus Einstein, namun teori gravitasi Newton dapat memprediksi dengan tepat bentuk dan orbit planet-planet dalam tata surya, sekalipun perhitungan dilakukan dengan anggapan bahwa gaya gravitasi bekerja dengan sesaat. Bahkan jika dianggap gravitasi tidak bekerja dalam waktu sesaat, sesuai dengan relativitas Einstein, maka orbit planet harus mengalami koreksi. Anehnya jika koreksi Einstein dimasukkan justru memberikan hasil prediksi orbit planet yang tidak sesuai dengan data astronomi. Berdasarkan hal tersebut Einstein membuat kesimpulan bahwa ada mekanisme yang belum dijelaskan pada teori gravitasi universal Newton.

Kejanggalan kedua yang ditemukan Einstein terkait dengan hukum gravitasi Newton adalah berhubungan dengan prinsip ekivalen. Prinsip ekivalen ini menggambarkan bahwa semua hukum fisika akan berperilaku sama dalam kerangka acuan mana saja, baik dalam kerangka diam maupun dalam kerangka yang bergerak dengan kecepatan konstan atau dengan laju kecepatan positif. Gagasan Newton menganggap innersia berhubungan dengan kerangka absolut ruang, artinya Newton meyakini adanya ruang absolut sebagai sumber gaya-gaya inersia (4muda, 2016). Hal tersebut bertentangan dengan teori relativitas Einstein dan menambah keraguan terhadap teori gravitasi Newton. Sebagai contoh anggaplah kita berada dalam pesawat ruang angkasa yang sedang berada di ruang hampa, pesawat bergerak ke atas dengan laju kecepatan yang sama dengan laju kecepatan gravitasi bumi yaitu $9,8 \mathrm{~m} / \mathrm{s} 2$, jika ada sebuah buku melayang di dalam pesawat itu, maka buku itu akan bergerak menuju lantai pesawat dengan laju yang sama pula dengan $9,8 \mathrm{~m} / \mathrm{s}^{2}$. Jika buku dengan berat yang sama dilepaskan dari ketinggian tertentu di bumi dalam pengaruh gravitasi bumi, maka buku itu akan jatuh ke bumi dengan laju kecepatan yang sama pula.

Kasus buku yang melayang dalam pesawat dan buku yang jatuh di dekat bumi dalam pengaruh gravitasi bumi tersebut kita tidak bisa membedakan geraknya apakah buku jatuh karena tarikan gravitasi bumi ataukah hanya sekedar bergerak dengan laju kecepatan yang sama dengan gravitasi bumi. Dengan demikian kita seolah-olah bisa menciptakan maupun menghilangkan gravitasi hanya dengan memandang dari kerangka acuan yang berbeda. Jika demikian mungkinkah buku tadi jatuh karena ditarik bumi ataukah sebaliknya bumi yang bergerak ke atas ke arah buku tadi dengan laju kecepatan sama dengan gravitasi bumi.

Dua kejanggalan teori gravitasi Newton yang dikemukakan di atas menjadi kunci bagi Einstein untuk mengungkapkan konsep gravitasi baru yang revolusioner. Teori gravitasi baru Einstein didasarkan pada cara pandang terhadap ruang dan waktu yang berbeda dengan yang dikemukakan Newton. Newton menganggap ruang angkasa sebagai ruang yang kosong, sedangkan Einstein menganggap ruang angkasa terbuat dari anyaman medan ruang dan waktu. Teori gravitasi baru einstein ini dikenal dengan nama teori relativitas umum. Teori gravitasi newton disusun menjadi sebuah persamaan. Sedangkan teori gravitasi baru Einstein disarikan menjadi 16 buah persamaan, dimana persamaan itu menghubungkan geometri ruang dan waktu dengan massa dan energi (Waluyo, 2004).

Medan ruang dan waktu adalah medan 4 dimensi, dimana 3 dimensi berasal dari ruang dan satu dimensi berasal dari waktu. Bentuk susunan anyaman ruang dan waktu sangat dipengaruhi oleh distribusi massa dan energi yang berada di dalam medan 4 dimensi itu. Benda-benda angkasa akan melekukkan medan ini, misalnya matahari akan melekukkan medan ini dan digambarkan seperti lekukan karpet yang di atasnya terdapat bola, namun sebenarnya lekukannya empat dimensi hanya gambaran dibuat dua dimensi untuk memudahkan. Fenomena ini lebih dikenal sebagai warped space time, atau ruang-waktu yang terlekuk.

Dua fisikawan berkebangsaan Austria Joseph Lense dan Hans Thirring memprediksi bahwa benda bermassa bisa merubah bentuk medan ruang dan waktu dengan cara lain pada tahun 1918, dua 
tahun setelah Einstein mengajukan teori relativitas umumnya. Mereka berpendapat bahwa setiap planet dan bintang yang berputar pada porosnya akan menyeret anyaman medan ruang dan waktu ke arah mana planet dan bintang berputar. Fenomena ini dikenal sebagai seretan kerangka atau framedragging.

Kemungkin teori yang dikemukakan oleh Einstein benar tetapi bukan berarti teori gravitasi Newton salah sama sekali. Sampai saat ini kedua teori tersebut masih sama-sama dipegang untuk memahami fenomena-fenomena alam. Dalam hal tertentu teori Einstein memberikan pengertian yang lebih akurat tentang alam semesta. Salah satu contohnya adalah bahwa menurut teori gravitasi Newton setiap planet bergerak mengelilingi matahari dalam lintasan orbit berbentuk ellips. Jika planet hanya satu yang mengelilingi matahari maka lintasan planet yang berbentuk ellips tidak akan berubah, namun kenyataannya banyak panet yang terdapat di tata surya, planet-planet lain ternyata juga memberikan pengaruh gravitasi kepada planet lainnya sehingga orbit planet tidak statis melainkan bergerak berputar (berpresisi) terhadap matahari. Teori relativitas Einstein sanggup menjelaskan pergeseran orbit planet yang tidak bisa dijelaskan oleh teori gravitasi Newton.

Fenomena terakhir yang diajukan Einstein berhubungan dengan hilangnya sebagian energi cahaya ketika melewati medan gravitasi, ketika energi cahaya kehilangan sebagian energi, maka panjang gelombang cahaya menjadi lebih panjang mengakibatkan warna cahaya bergeser ke arah warna merah, fenomena ini disebut sebagai pergeseran warna merah akibat medan gravitasi.

Hasil pengamatan lapangan yang dilakukan para ilmuwan masih menyisakan pekerjan rumah bagi fisikawan untuk membuktikan kebenaran teori Einstein. Itulah sebabnya NASA membuat sebuah proyek Gravity Probe B (GP B) yang membutuhkan waktu 40 tahun, dan satelit GP B baru dapat mengorbit pada bulan Mei tahun 2004. "Meskipun terlihat sangat indah, kemungkinan besar teori relativitas umum Eisntein akan mengalami amandemen" (C.N. Yang, Pemenang hadiah nobel fisika) (Waluyo, 2004).

Einstein ternyata mengakui sendiri bahwa persamaan relativitas umumnya memiliki kelemahan, ia menyataan bahwa suku sisi kiri persamaannya yang menggambarkan geometri ruang dan waktu, merupakan suku yang kokoh, sedangkan suku kanan persamaannya adalah suku yang lemah. Kesulitan-kesulitan yang ditemui para fisikawan dalam persamaan relativitas Einstein menguatkan kecurigaan bahwa teori ini perlu diamandemen. Untuk menemukan bukti kuat yang dapat mendukung amandemen teori gravitasi Einstein ini dibuatkan proyek Gravity Probe B (GP B) (Waluyo, 2004).

\section{PENUTUP}

Fenomena alam tentang kecenderungan benda-benda jatuh menuju pusat bumi dan keteraturan peredaran planet dan benda-benda langit lainnya mengelilingi matahari dalam tata surya menjadi pertanyaan fundamental dan keduanya dijelaskan dengan hukum gravitasi. Hukum gravitasi Newton mampu menjelaskan fenomena benda jatuh dan keteraturan gerak planet dalam tata surya, tetapi belum mampu menjelaskan pergeseran orbit planet.Teori relativitas Einstein belum sepenuhnya mampu mengatasi kelemahan teori gravitasi Newton dan masih dalam penyelidikan kemungkinannya untuk diamandemen.

\section{DAFTAR PUSTAKA}

Dahlan, Ahmad. Hakikat Epistimologi Dalam Kajian Filsafat Ilmu. Tersedia: http: //www.eurekapendidikan.com/ 2014/10/ hakikat-epistimologi-dalam-kajian-Filsafat-Ilmu.html. Diakses: 6 April 2017 
4muda. (2016). Gravitasi ala Newton: Keberhasilan dan Permasalahannya. Tersedia: http://4muda.com/gravitasi-la-newton-keberhasilan-dan-permasalahannya/. Diakses: 6 April 2017

Firman, Harry. (2017). Filsafat: Pengantar Filsafat. Bahan kuliah filsafat ilmu. Tidak diterbitkan. Bandung: SPs UPI.

Kuhn, Thomas S. (2008). The Structure Of Scientific Revolution, Peran Paradigma dalam Revolusi Sains. Bandung: PT. Remaja Rosdakarya.

Rapar, J. H. (1995). Pengantar Filsafat. Jakarta: Kanisius

Stiyani, Anis. (2014). Teori Benda Jatuh Menurut Galileo Galilei dan Aristoteles. Tersedia: http://anicestea. blogspot.co.id/2014/09/teori-benda-jatuh-menurut-galileo.html. diakses tanggal : 7 April 2017.

Suriasumantri, Jujun S. (2009). Filsafat Ilmu Sebuah Pengantar Populer. Jakarta: Pustaka Sinar Harapan.

Waluyo, Agung. (2004). Teori fisika : Menguji Teori Gravitasi Einstein. Tersedia: http://www.fisikanet.lipi.go.id/utama.cgi?cetakartikel\&1100397070. Diakses tanggal : 9 April 2017.

Wospakrik, Hans J. (1987). Mengenang 300 Tahun : Teori Gaya Berat Newton. tersedia:: http://www.fisikanet.lipi.go.id/utama.cgi?cetakartikel\&1110895525. Diakses: 7 April 2017.

--------.. (2015). Sejarah Perkembangan Teori Gravitasi. Tersedia: http://www.fisikainfo. com/2015/11/sejarah-perkembangan-teori-gravitasi.html\#. diakses tanggal: 9 April 2017. 